\title{
Universities and Knowledge Production in Central Europe
}

\author{
MAREK KWIEK \\ Centre for Public Policy Studies, Poznan University, Poland
}

\begin{abstract}
The article discusses an East/West divide in Europe in university knowledge production. It argues that the communist and post-communist legacies in the four major Central European economies studied (Poland, Hungary, the Czech Republic and the Slovak Republic) matter substantially for educational and research systems. The differences in university knowledge production may be bigger than expected, and the role of historical legacies may be more long term than generally assumed in both social sciences and public policy studies on the region. The gradual convergence of both higher education and research systems in two parts of Europe cannot be taken for granted without thoughtful changes in both university funding (both modes and levels) and governance. The article discusses links between knowledge production, economic competitiveness and regulatory and other environments in which both universities and knowledge-intensive companies operate. The role of factors other than higher education and innovation systems is substantially more important for competitiveness and growth in Central Europe than in affluent Western economies. The international visibility of universities as knowledge production centres is low and the analysis of the geography of knowledge production at the level of regions may indicate that Central Europe is in danger of being effectively cut off from the emergent European Research Area.
\end{abstract}

\section{Introduction}

The article discusses an ongoing East/West divide in Europe in knowledge production and links it to historical differences (in communist and post-communist periods) between the economy, society, higher education and research and development systems in two parts of Europe.[1] It argues that the communist legacy in the four major Central European economies studied (Poland, Hungary, the Czech Republic and the Slovak Republic) matters substantially for educational and research systems. But also the post-communist legacy of the first decade of the transition period (the 1990s) matters as universities in the region are more teaching-focused than involved in traditional research-based knowledge production. The article then discusses the role of communist and post-communist legacies in knowledge production and goes on to briefly analyse higher education reforms and the low visibility of Central European universities in global and European university rankings. The core of the article is in the final sections, which discuss links between knowledge production, economic competitiveness and regulatory and other environments in which universities and knowledge intensive companies operate. The discussion in these sections is based on international comparisons of economic competitiveness for the simple reason that higher education and innovation sectors have become substantial parts of global business, and in the knowledge economy discourse, competitiveness ranking exercises and universities potentially became part of the solution to current economic problems.

The article argues that Central European economies are not globally competitive, not only because they lag behind in higher education and innovation, but because they lag behind in other economic pillars as well. There is a wide, although slowly bridged, East/West gap related to a 
multitude of factors, from tax systems to legal systems to transportation infrastructure. Higher education and innovation systems in Central Europe function in much less competitive economies, and companies, including those involved in research, development and innovation, operate in less friendly legal and regulatory environments. All these factors influence the level of university- and business-sector knowledge production.

In the knowledge economy, knowledge has become the crucial source of added value (Stehr, 2002, p. 17). Definitions of the knowledge economy abound; as Foray puts it:
by knowledge-based economies I mean, essentially, economies in which the proportion of knowledge-intensive jobs is high, the economic weight of information sectors is a determining factor, and the share of intangible capital is greater than that of tangible capital in the overall stock of real capital. (Foray, 2006, p. ix; see also Stehr, 1994; Leydesdorff, 2006)

There seem to be no fundamental differences between understandings of the concept of the knowledge economy in social sciences and in international organisations. As the World Bank defined it recently:
A knowledge economy is one in which knowledge assets are deliberately accorded more importance than capital and labor assets, and where the quantity and sophistication of the knowledge pervading economic and societal activities reaches very high levels. (World Bank, 2007, p. 14; see also OECD, 1996)

This article explores the question of knowledge production in Central Europe in the context of the knowledge economy and economic competitiveness.[2] I argue that, today, Central European economies are not 'knowledge economies' to the same extent that their more affluent and technologically advanced Western European counterparts are. Therefore, one of the major themes of the article is an ongoing East/West divide in knowledge production resulting from historical differences between the economy, society, and higher education and research and development systems in both parts of Europe. I also argue that the communist legacy in Central European countries matters substantially: it matters for their economies, in transition to market economies; it matters for their societies, in transition to what are sometimes termed 'post-communist welfare states'; and it matters for both educational and research and innovation systems that are crucial for knowledge production. The three areas (economies, societies, and higher education and research systems) are closely interlinked, and an assessment of knowledge production requires an analysis of their interrelations.

The question is: to what extent is the divide between knowledge production in Central Europe and in major Western European economies today driven by hard factors (difficult to change in the medium term), and to what extent it is driven by soft factors (more easily changeable)? The former factors include: levels of public funding in higher education and research systems; the social and age structure of the workforce by levels of education and by types of profession; the structure of employment by major economic sectors; and the overall national level of economic competitiveness. The latter - soft - factors include: funding modes and governance modes in higher education and research systems; access policies in higher education; the matching of education systems and the labour market; and the majority of factors related to business, legal and institutional environments (as, for instance, reported annually by the World Bank via the 'ease of doing business' indicators [World Bank, 2010]).

Both hard and soft factors link the patterns of ongoing knowledge production in the region to the communist and post-communist legacies. Social and economic change takes time and, from a current perspective, the two decades of transformation (1990-2010) are not enough to bridge the gap between the East and the West in knowledge production. Universities in Central Europe are changing, sometimes rapidly but most often gradually, but Western European universities have been changing even more rapidly in the last twenty years, as comparative studies indicate (see Bonaccorsi \& Daraio, 2007; Maassen \& Olsen, 2007; Shattock, 2008). As commentators note about public services in general in the region (and this can also be applied to higher education), 'social transformation, including the adoption of a new value system and social behavioral pattern, is not a process of one or two decades. It takes generations. Based on the economic and political transformation, gradual social adjustment may follow. History, however, remains part of the present for a long time' (Berend, 2007, p. 279). 
Universities in Central Europe are desperately struggling to remain in the outer layers of the dramatically changing global academic centre. Without thoughtful higher education and research policies, combined with radically increased research funding and new funding modes, they might move from the outer layers of the centre to the global academic periphery (Kwiek, 2009; Kwiek \& Maassen, forthcoming). Central European academics and policymakers in charge of higher education seem to believe in three interrelated myths: (1) the myth that post-communist universities, due to their history, are exceptional in Europe, and their exceptionality should be preserved (exceptional in terms of being systematically inward-looking and academically driven institutions, isolated from concerns of both society and the economy); (2) the myth that postcommunist universities as public sector institutions are radically different from all other publicsector institutions, and immune from the impact of global and European public-sector reforms; and (3) the myth that knowledge production can be more visible in reformed (in both funding and governance modes) higher education systems, even with current low public expenditures on research and development. The three myths have been powerful inhibitors to knowledge production in the region and have been shared throughout the two decades of the transition and accession period by academics and policymakers. Combined, they have contributed to both real and perceived decline in university knowledge production.

\section{Knowledge Production and Historical Legacies: communist and post-communist periods}

Knowledge production in Central European economies is strongly linked to their legacies of operating for fifty years in command-driven communist economies, and to wider post-communist transition processes in the last twenty years. The historical legacies relevant for the knowledge production in the region include the following parameters: economy and society (rather than merely politics); public services (social policies, leading to the 'emerging' welfare states, as opposed to 'established' welfare states [Castles et al, 2010]); higher education policies (including, especially, governance and funding reforms); and research and innovation policies (especially those related to academic entrepreneurialism and university-enterprise partnerships [Kwiek, 2008a, b; Temple, 2008]). This section discusses first the dramatically changing social context of knowledge production in communist and post-communist periods, and then its radically different fiscal context. Finally, it shows how universities in Central Europe have not been able to produce convincing social and institutional narratives or founding ideas in defence of their traditional roles in society. Consequently, especially in the 1990s, universities were seen as tools for educational expansion rather than primarily as knowledge-generating institutions.

Communist-era higher education and research systems and their knowledge production in Central Europe differed substantially from their Western European counterparts in the following ways: it had a heavily centralised higher education system, with attempts at balancing the number of graduates with the number of jobs, with displaced job competition, and with educational credentials more important in job allocation than actual knowledge or skills; there were curriculum guidelines, research goals, and requirements for filling teaching positions defined and closely monitored by the Communist Party; there was a unitary system of traditional university education, with no bachelor's programmes; the number of students admitted and the enrolment procedures were based on quotas set for controlling the proportions of students from various social backgrounds; and the financing of universities was entirely dependent on the government (Mateju et al, 2007, pp. 374-375). All these points are no longer valid, but the removal of their legacy is what was happening, at various speeds, during the past twenty years, with different reform programmes. The current shape of universities and knowledge production in Central Europe is determined by specific factors defining both the communist and post-communist transition periods (as is the case with social policies; see Tomka, 2005). It would be unfair to deny the large extent to which Central European universities have been transformed in the last two decades. But knowledge production in the region cannot escape its recent history: after being viewed as strategic, bureaucratic elements of communist regimes, universities in the first decade of the transition period were largely left on their own, autonomous but severely underfunded, and engaged much more in (mostly fee-based) teaching than in traditional knowledge production. 
The fiscal context in which knowledge is produced in universities and in which universities operate in Central Europe is of critical importance for the present discussion. In post-communist Central Europe, there has been a continuing conflict between the need for high-quality higher education and powerful fiscal constraints, especially in the 1990s, when higher education systems were under the first wave of reform pressures (for details, see Cunning et al, 2007, p. 29). Central European countries in general have similar funding modes for financing public higher education: financial aid to students is combined with the avoidance of charging them tuition fees. A dual-track system is prevalent in the region: fee-free higher education is available for regular students (disproportionately coming from socially and economically privileged families - with only Poland being an 'equity success story', showing decreasing inequality in access to higher education [Kwiek, 2007, 2008c, 2009]), admission is via competitive entrance exams, and a special fee-paying track is available for those who fail to gain admission - which tends to cpenalize students from disadvantaged families' (Cunning et al, 2007, p. 29) and raises serious equity concerns. Funding modes for both higher education and research performed in higher education, most often in separate streams, have had powerful and long-term impacts on knowledge production in universities: generally, the focus of universities in Central Europe, especially in the 1990s, has been on the teaching mission. The research mission (as well as various types of third mission - for instance, the service to the society mission, the regional mission and the entrepreneurial mission [see Arbo \& Benneworth, 2007; Shattock, 2008]), in general, has been systematically denigrated throughout the region for almost two decades, despite differences between the four countries, related to various attempts at reforming governance and funding patterns, especially in the 2000s the Polish reforms of 2008-2011 being an interesting example of introducing 'new rules of the game' (see Kwiek \& Maassen, 2011). Drastic public underfunding of universities in the 1990s led both academic institutions and individual academics to apply various 'survival strategies', related mostly to introducing fee-based university programmes for part-time students in public universities and teaching in private higher education institutions by academics from public institutions (on the two types of privatisation, see Kwiek, 2010; and on the emergent public-private dynamics in higher education, see Kwiek, 2011). The survival strategies have led to research underperformance: both institutions and academics alike were focusing on teaching (for various post-communist countries, see chapters in Tomusk, 2004; Scott, 2007a,b; Slantcheva \& Levy, 2007).

But do almost half a century of operating under the communist regime and two decades under transition conditions explain sufficiently the current differences that exist in overall research performance levels of higher education systems in Central Europe compared with EU-15 economies? What is the long-term impact of a different academic culture (or of different academic cultures) in Central European countries under communism, including different governance and funding regimes and the lack of academic freedom and institutional autonomy? What is the impact of what Elster et al (with reference to economies) called 'the long arm of the past' (1998, p. 158) in the area of knowledge production? As stressed by analysts of social policy generally, much more attention is currently paid by academics to the legacies of the past and the ways in which these legacies 'influence meaningful change' today (Inglot, 2005, p. 5; see Inglot, 2008). The current article shows that higher education functions in a complicated ecology of institutions and that they are all heavily reliant on their economic, legal, regulatory, tax, and infrastructural underpinnings.

There were three major effects of the post-1989 transition, all relevant for trajectories of transformation of higher education systems: (1) the distribution of income and earnings widened; (3) output fell and tax revenues fell even more sharply; and (3) job security ended (Barr, 2001, pp. 242-243). In the 1990s, a relatively stable social and economic environment in which knowledge was produced in communist-period universities was disintegrating, leading to new institutional and individual 'survival strategies' in the higher education sector. New institutional norms and behaviours emerged, together with institutional autonomy and academic freedom, regained immediately following the collapse of communism. But autonomy was accompanied by severe financial constraints: long-term systemic financial austerity was the trademark of university knowledge production in the region throughout the 1990s, and its impact on higher education systems, institutions and individual academics has been substantial (Tomusk, 2004; Kwiek, 2011).

From a historical perspective, universities in Central Europe, Poland included, are not able to produce convincing social and institutional narratives in defence of their traditional roles in society - as their historical rootedness is either too far-reaching into the past (that is, too explicitly 
Humboldtian), or too idiosyncratic and 'tainted' by the period of communism. In both cases, their historical rootedness, and the resulting narratives linking their past to their future, are viewed by Central European policy makers and the media as interesting but largely irrelevant for current and future challenges.

In the absence of convincing narratives about universities produced by universities themselves, new narratives are increasingly produced by the state, especially governments involved in reform programmes. Not surprisingly, in these new narratives (for instance, the 2005-2008 narratives, and especially the 2008-2010 narratives about the need for reforms in Poland), universities are viewed as 'instruments for national political agendas' rather than as 'institutions' (to use Olsen's distinction; see Maassen $\&$ Olsen, 2007). Universities seem unable to protect both their institutional identities and their institutional integrity, unable to produce and promote a common, socially convincing narrative about the social, cultural and economic future of academic institutions. Institutions without powerful founding ideas at their disposal are much more easily subject to radical reform programmes - which is the Polish case for 2008-2011 and beyond.

What seems to matter more for the strength of the instrumental view of the university that is prevalent in the region is the relatively weak rootedness of traditional organisational and funding patterns: both the communist period and the two decades of post-communist transformations have not been strong enough, or legitimate enough, reference points for the production of convincing narratives based on the vision of the university as a community of scholars. Consequently, universities in the region - if, as in Poland, they are exposed to the pressures of comprehensive instrumental reform - seem much weaker partners in a stakeholders' dialogue about their future than universities in Western Europe.

And the consequences for university knowledge production are manifold: first, in the absence of powerful, socially accepted narratives linking universities' past, present and future, governance and funding reforms in the last two decades were much less substantial than they could be, and were often merely cosmetic. Public interest in universities focused on their increasing teaching capacities, and on increasing enrolment rates, together with the policy fascination (although often not without disgust) with increasing enrolments in the newly created private sector that was in search of legitimacy' (Slantcheva \& Levy, 2007, pp. 1-26) in the region. The identity crisis of the academic profession, caused, inter alia, by severe institutional underfunding and low academic salaries, led to a decade of weak, cosmetic reforms; this caused the public to lose interest in universities as knowledge-generating institutions, and, consequently, caused policymakers to lose interest in the university research mission.

\section{Knowledge Production and Reforming Higher Education in the Region}

Knowledge production in the region today is also strongly linked to generally low interest among policymakers in university research and university reforms, leading to their higher international research visibility. In the early years of the transition period, both domestic and, especially, international policy actors were paying little attention to social policies in general and to higher education policies in particular (setting up unemployment systems was the only area of priority concern at that time): neoliberal policymakers focused on stabilisation, liberalisation, and privatisation policies (Orenstein \& Haas, 2005, pp. 145ff.). The neoliberal 'Washington Consensus' 'had little to say on the social-sector restructuring that was to become such a large part of postcommunist transformation' (Orenstein, 2008, p. 85). The process of reforming social policies in Central Europe during the post-communist era turned out to be 'much longer and much more difficult than most experts anticipated' (Inglot, 2005, p. 3). Nevertheless, a 'surprisingly long distance from the Soviet Bloc to the European Union' was covered in 'historically [an] extremely short period of time' (Berend, 2007, p. 269). The general lack of reformers' focus on higher education, and the general fascination of both the public and policymakers with the single indicator of student numbers, had far-reaching consequences for knowledge production: the teaching mission became the core university mission.

Most prominent political figures and their advisors involved in Polish economic reforms of the early and mid-1990s (notably Leszek Balcerowicz and Jeffrey Sachs) hardly mentioned the need for reform of teaching and research. Poland was not an exception: the lack of higher education 
reforms was prevalent in Central Europe, perhaps partly owing to western views that communist educational systems did not need substantial transformation, in contrast to their economic and political systems. It needs to be added, by way of justification, though, that in the region in the 1990s the creation of 'the very fundamentals of capitalism' took place; not surprisingly, 'in Eastern Europe, both markets and private enterprises were virtually non-existent for about 40 years' (Elster et al, 1998, p. 157). It is perhaps only from a safe distance of almost two decades of 'transition' and 'accession' that we can criticise the missing dimension (higher education reforms) in Central Europe in the 1990s and stress its role in the ongoing East/West divide in knowledge production.

As a consequence of at least a decade of neglect (i.e. the 1990s) of the reform of higher education and severe underfunding of university research, the amount of Central European knowledge production seems low from a Western European comparative perspective. There is a continuing absence of Central European universities in global (and especially European) university rankings. In 2010, only five universities from the region were present in the Academic Ranking of World Universities: one in the 210-300 ranking (Charles University in Prague, the Czech Republic), and four in the 301-400 ranking (Warsaw University and Jagiellonian University in Poland; Eotvos Lorand University and University of Szeged in Hungary). No university from the Slovak Republic (or from Romania or Bulgaria) was ranked in top 500 world universities. No university in Central Europe is located in top 100 world universities in terms of either subject (such as chemistry) or field (such as social sciences). The ranking is dominated by American universities: in the top 10, there are only two European universities (Cambridge ranked 5th and Oxford ranked 10th), and in the top 20 there is only one other non-American university, the University of Tokyo (ranked 20th). In the top 200 world universities published by The Times Higher Education Supplement in 2010, there are no institutions from Central Europe. And among the top 100 European universities, there are none from the region. This absence does not support the main argument of the article - that the comparatively low economic competitiveness of Central European economies is mostly linked not to their uncompetitive higher education, training and innovation sectors, but to their lagging behind in many other areas, including infrastructure and regulatory environment - but it does illustrate how universities in the region compare with Western European universities. There are different objections to university rankings and their methodologies (see e.g. Hazelkorn, 2011; Teichler, 2011), but the fact is that Central European universities are not once but permanently absent from these rankings.

\section{Knowledge Production in Central Europe and Economic Competitiveness}

Generally, in a world in which the economic dimension is viewed by policymakers as increasingly important in assessing countries in general and their higher education systems in particular (compared with the traditional social dimension), rankings of economic competitiveness based inter alia on assessments of higher education and research and innovation systems can hardly be ignored. In particular, they should not be ignored in post-communist countries aggressively seeking foreign direct investment. Both national economies and universities themselves are increasingly ranked and assessed according to standardised global measures. Universities are increasingly constructed as organisations (rather than as merely institutions - what Ramirez [2006] called their 'rationalization' - see Brunsson \& Sahlin-Andersson, 2000), internationally compared and ranked. As Meyer at al (2007) stress, the modern university in a globalised and rationalised world is a 'purposive actor':

In this world of imagined homogeneity, standardized dimensions of ranking, certification, and accreditation make sense. Universities around the world can be compared and rated on standard scales. And if they are effectively and purposively managed organizations, perhaps they can improve their rankings vis-à-vis all the other universities in the world. (p. 206)

The discussion of Central European knowledge production in the next two sections is based on international comparisons and refers to two global indexes: the Global Competitiveness Index (The Global Competitiveness Report 2010-2011) and the Doing Business 2010 Index.[3] A study of indicators provided in the two rankings is viewed as an alternative to a more standard study of international data (such as those provided by UNESCO or OECD). The reason is that global indexes are appealing to the business community, the media and the public at large, despite their relative 
simplicity. Higher education and innovation sectors became substantial parts of the global business or competitiveness ranking exercises and, potentially, in the knowledge economy discourse, they became part of the solution to current economic problems (as a commentator noted, 'an expert system of measurement was institutionalized, constructing a social reality for governments and others establishing a potential to act as if nations compete' [Pedersen, 2010, p. 635]).

The major point here is that economic competitiveness is not determined by higher education and innovation pillars in Central European countries to the same extent as it is in affluent OECD economies. Michael Porter's higher education and training and innovation 'pillars of competitiveness', compared with other pillars of competitiveness, seem to be substantially less important. Central European economies, compared with major European economies, still severely lag behind in most of the other pillars; lagging behind is structural and extremely difficult to overcome, and requires both time and funding, counted in years, if not decades, and (mostly public) investments counted in dozens, if not hundreds, of billions of euros. At the same time, expectations of higher education and public R\&D and innovation systems by both governments and the general public in the region regarding economic competitiveness are very high; we view them here as largely exaggerated, due to numerous other factors exogenous to the two systems.[4]

An almost automatic passage from (high) levels of individuals' earnings premium in higher education to (high) levels of economic growth of countries based on the strength of their (higher) education systems is often taken for granted. Central European economies still have the highest wage premium on higher education in the OECD area (for a decade they have been in the top five countries), while their knowledge production is relatively low, and their economic competitiveness is modest. We argue here that for Central Europe, the remaining ten 'pillars of competitiveness' are of critical importance, and without progress in those pillars, the higher education and innovation pillars studied in this article lose the fundamental role that they have in Western European 'knowledge economies'. We argue that it is difficult for higher education and innovation systems to go beyond their national social and economic contexts: they belong to national legal and infrastructural settings and are regulated by national arrangements, are funded from national taxes, and produce graduates with skills necessary for national economies. The national settings are, for higher education and innovation systems, both burdens and challenges (see Arbo \& Benneworth, 2007).

Higher education systems in Central European countries today face generally the same challenges as those in other OECD countries, but in a doubly unfriendly context of the need to change the structure (and focus) of their former educational systems, while operating in tough fiscal and economic environments (Barr, 2005). The four Central European countries discussed here have the most expanding higher education systems in the OECD area: they are among the top six OECD countries with the highest increase in the number of students in higher education between 1995 and 2004, with the first three ranks belonging to Poland, Hungary and the Czech Republic (OECD, 2008, p. 30). But the massification of higher education in Central Europe took place in a specific context. As Nicholas Barr stressed, in EU accession countries, the governments were caught between conflicting imperatives:

the constraints of the Stability and Growth Pact, and the demands of other parts of the public sector - unemployment benefits, active labor market policies, poverty relief, and policies to address social exclusion, pensions, healthcare, and school education. The resources to finance mass, high-quality higher education from taxation were simply not there. (Barr, 2005, p. 243)

One of the implications is that the numerical expansion of higher education occurred mostly in cheap-to-run programmes, with a strong fee-based (rather than tax-based) private sector wherever relevant, and with a strong negative correlation with the quality of education - and this is the Polish case. Polish universities shifted their institutional attention away from joint research and teaching missions, to teaching missions, as fees guaranteed an additional income stream - and now, re-focusing attention back to research and teaching missions, after almost twenty years of neglect, is difficult to achieve.

Let me follow here the notion of economic competitiveness developed by Michael Porter (Porter, 1990) and used in annual Global Competitiveness Reports (Porter et al, 2008; Schwab, 2010). Macroeconomic, political, legal and social circumstances underpin a successful economy - but are not in themselves sufficient: 'wealth is actually created in an economy at the microeconomic level - 
in the ability of firms to create valuable goods and services using efficient methods. Only firms can create wealth, not government or other societal institutions' (Porter et al, 2008, p. 53). So, on this view, economic competitiveness and productivity ultimately depend on the microeconomic capability of the economy. It is not only companies that compete - nations compete too: Porter 'highlighted the importance of the locality in which a company was embedded and showed that the social, political, macroeconomic, and legal context had an influence on the competitiveness of firms' (Pedersen, 2010). In the competition between nations, all seeking their 'comparative advantages', higher education and innovation systems are viewed as increasingly important in knowledge economies. This article highlights the idea that in less competitive regions of the world the two systems are less important and their reforms lead to less clear results, despite enormous hopes cherished by the reformers.

Knowledge production in Central Europe is viewed in this section in the context of different types of economic competitiveness. Higher education can play different roles in different OECD countries as their economies are driven by different types of competitiveness (related to different stages of economic development). Only the Czech Republic is driven by the same type of competitiveness as the most affluent OECD countries. Poland, the Slovak Republic and Hungary (as well as Latvia, Lithuania and Romania) are in a transition stage. And Bulgaria is in the second, lower stage of development, while other post-communist countries outside the European Union, such as the Russian Federation, Ukraine, Kazakhstan or Moldova, are in the lower, first stage, or in a transition stage between the first and second stages. The role of (higher) education is different in each of the three stages and economic growth is faced with different competitiveness challenges in each of them, in Porter's analytical framework. As nations develop, their competitive advantages and modes of competing move from the factor-driven stage (low-cost labour, natural resources) to the investment-driven stage (foreign technology, imitation), to the highest one - the innovationdriven stage (innovative products and services at the global technology frontier, as elaborated by Michael E. Porter in 1990 for the first time in The Competitive Advantage of Nations [see Porter, 1990, pp. 543-574]; on the institutionalisation of the discussion about how nations compete via institutions and expert systems, see Pedersen, 2010, pp. 630-657).

Discussions on knowledge production in post-communist Europe cannot ignore a fundamental distinction between efficiency-driven growth in such European countries as Albania or Bulgaria, almost innovation-driven growth (in transition between the second and third stages of economic development in this classification) in Hungary, the Slovak Republic, Poland and Romania, and, finally, innovation-driven growth in the Czech Republic.

Of the twelve pillars of competitiveness (Schwab, 2010), two are of special interest: "higher education and training' and 'innovation'. While most major OECD economies are ranked in the first two deciles of the index, the four Central European countries are in the fourth, fifth and sixth deciles of it (the Czech Republic is ranked 36th, Poland ranked 39th, the Slovak Republic ranked 60th, and Hungary ranked 52nd; additionally, Romania is ranked 67th and Bulgaria 71st).

Not surprisingly, in the context of Central Europe, what seems to matter much less for the economic competitiveness from a larger perspective is enrolments in education (certainly with all countries below already representing 'massified' systems) - both in secondary education (Switzerland ranked 38th, Singapore 30th and Sweden ranked 13th) and in tertiary education (Switzerland ranked 38th, Singapore 30th and Sweden 16th). The four Central European countries discussed in this article are relatively well ranked in terms of tertiary enrolments (Hungary ranked 23rd, Poland 21st, the Czech Republic 32nd and the Slovak Republic 40th), and relatively weakly ranked in terms both of the university-industry collaboration in R\&D (the Czech Republic ranked 29th, Hungary 32nd, Poland 64th and the Slovak Republic 87th) and the extent of staff training (the Czech Republic ranked 40th, Poland ranked 52nd, the Slovak Republic ranked 75th and Hungary ranked 88th).

Let me focus on Poland, the Slovak Republic and Hungary (and two other newer EU member states, non-OECD members Romania and Bulgaria), considerably less competitive economies than the Czech Republic. Where are the weak and the strong points in their tertiary education and training pillar and in their innovation pillar? The details are given in Tables I and II. Overall, Hungary is ranked high in the higher education and innovation pillars (34th and 41st, respectively), while Poland is ranked high in the higher education pillar and low in the innovation pillar (26th and 54th, respectively). The Slovak Republic is ranked low in both pillars (53rd and 85th, respectively). 
The strong points for both Poland and Hungary in the higher education and training pillar are certainly tertiary enrolments; strong points for Hungary and Poland are the quality of mathematics and science education; Internet access in schools is strong in Hungary; the quality of the educational system is ranked low for Poland and dramatically low for both Hungary and the Slovak Republic; the quality of management schools is again low for Poland and dramatically low for both Hungary and the Slovak Republic; local availability of specialised and training services is relatively good only for Poland; and finally, the extent of staff training is very low for all three countries. In the sub-indices for innovation, the three Central European economies rank low (about 40th-50th) or dramatically low (about 70th-80th) in all: they rank low in 'capacity for innovation', dramatically low in 'quality of scientific research institutions' (except for Hungary), 'company spending on R\&D', and 'university-industry collaboration in R\&D' (except for Hungary); they also rank low in 'availability of scientists and engineers' and in 'utility patents' (again, except for Hungary).

\begin{tabular}{|c|c|c|c|c|c|c|}
\hline Indicators & Poland & Hungary & $\begin{array}{c}\text { Czech } \\
\text { Republic }\end{array}$ & $\begin{array}{c}\text { Slovak } \\
\text { Republic }\end{array}$ & Bulgaria & Romania \\
\hline Secondary education enrolment rate & 25 & 33 & 42 & 50 & 66 & 54 \\
\hline Tertiary education enrolment rate & 21 & 23 & 32 & 40 & 46 & 22 \\
\hline Quality of the educational system & 62 & 75 & 34 & 111 & 85 & 84 \\
\hline Quality of maths and science education & 40 & 30 & 25 & 65 & 69 & 43 \\
\hline Quality of management schools & 62 & 71 & 56 & 114 & 94 & 98 \\
\hline Internet access in schools & 48 & 31 & 24 & 35 & 45 & 55 \\
\hline $\begin{array}{l}\text { Local availability of specialised research } \\
\text { and training services }\end{array}$ & 22 & 47 & 17 & 41 & 80 & 95 \\
\hline Extent of staff training & 52 & 88 & 40 & 75 & 135 & 72 \\
\hline
\end{tabular}

Table I. Ranks by indicators of the 'higher education and training' section.

Source: Schwab, 2010, pp. 111-299; author’s own calculations.

\begin{tabular}{|c|c|c|c|c|c|c|}
\hline Indicators & Poland & Hungary & $\begin{array}{c}\text { Czech } \\
\text { Republic }\end{array}$ & $\begin{array}{c}\text { Slovak } \\
\text { Republic }\end{array}$ & Bulgaria & Romania \\
\hline Capacity for innovation & 50 & 46 & 24 & 69 & 79 & 72 \\
\hline Quality of scientific research institutions & 47 & 18 & 21 & 90 & 73 & 83 \\
\hline Company spending on R\&D & 61 & 75 & 25 & 68 & 96 & 103 \\
\hline University-industry collaboration in R\&D & 64 & 32 & 29 & 87 & 110 & 103 \\
\hline $\begin{array}{l}\text { Government procurement of advanced } \\
\text { tech products }\end{array}$ & 61 & 106 & 31 & 127 & 87 & 105 \\
\hline Availability of scientists and engineers & 60 & 48 & 50 & 71 & 77 & 55 \\
\hline Utility patents per million population & 54 & 32 & 34 & 44 & 31 & 62 \\
\hline
\end{tabular}

Table II. Ranks by indicators of the 'innovation' section.

Source: Schwab, 2010, pp. 111-299; author’s own calculations.

Consequently, in the areas most important for knowledge production in global competitiveness index, the three Central European economies are ranked generally low, and in some specific cases, dramatically low. But even if they were ranked high in these areas, their overall economic competitiveness would be still very low due to low (or, in some cases, dramatically low) rankings in other standardised and measurable pillars, not related to higher education and innovation systems. And this is the point I want to stress: Central European economies are not globally competitive not only because they lag behind in higher education and innovation pillars of economic competitiveness; they lag behind in the other pillars as well. Consequently, even much more modernised higher education and innovation systems would not necessarily improve their economies' competitiveness. There is a wide, although slowly bridged, East/West gap related to a multitude of factors, from tax systems to legal systems to transportation infrastructure. Knowledge production in universities in the region cannot be assessed in isolation from their economic environments. Higher education institutions cannot be held solely responsible for low economic competitiveness, and higher education reforms cannot be expected to bear (economic) results as quickly as policymakers in the region expect. 


\section{Knowledge Production and its Environments}

In this section we discuss, first, the link between knowledge production in universities and in the business sector and regulatory settings in which companies operate. Then we place knowledge production in tough fiscal contexts in which infrastructural needs of Central European economies may act as powerful fiscal constraints, and in labour-market contexts in which the share of knowledge-intensive service activities is smaller than in most advanced OECD countries. Finally, the article refers to Central European regions, rather than countries, as units of analysis, to show the scope of the East/West divide in the European Union.

Knowledge production in universities and in business occurs in regulatory environments which cannot be easily avoided by either universities or companies. In universities, it is funding and governance regimes that matter most, in the business sector, it is often 'ease of doing business'. To show the differences between major OECD economies and the four Central European countries, let me refer briefly to the 'ease of doing business' ranking (at the microeconomic level of companies), annually measured by the World Bank in the last five years, most recently in Doing Business 2011: making a difference for entrepreneurs (World Bank, 2010).

Within a framework provided by the World Bank, there are ten categories in which comparative advantages of countries are sought: starting a business; dealing with construction permits; employing workers; registering property; getting credit; protecting investors; paying taxes; trading across borders; enforcing contracts; and closing a business. Central European countries are scattered along the ranks, with the Slovak Republic and Hungary ranking 41st and 46th, followed by Poland and the Czech Republic almost in the middle of the ranks (70th and 63rd) (World Bank, 2010, p. 4). Top OECD economies are in the top thirty ranks, with Singapore, Hong Kong (China), New Zealand, the UK and the USA in the first five ranks. These are the regulatory realities in which Central European economies are operating, which go far beyond (higher) education and innovation systems and directly or indirectly influence national economic competitiveness. As recent research tends to show (Shattock, 2008; Mora et al, 2010), these realities also, mostly indirectly, influence two areas in between universities and companies where knowledge production occurs: academic entrepreneurialism, and university-enterprise partnerships.

What are the advantages of the Slovak Republic and Hungary over Poland and the Czech Republic? Poland's weaknesses are clear: it is ranked higher than 100 (out of 183 countries) in such categories as starting a business (rank 113), dealing with construction permits (rank 164) and paying taxes (rank 121). The Czech Republic is ranked over 100 in two categories: starting a business (rank 130) and paying taxes (rank 128). And not surprisingly, all four Central European countries are ranked around 120 (ranks 121-128, with the lowest rank for Hungary - 109) in a single category paying taxes, with between 257 and 557 hours spent on taxes per year (World Bank, 2010, pp. 159-193). The details ate given in Table III.

\begin{tabular}{|c|c|c|c|c|c|c|}
\hline Indicators & Poland & Hungary & $\begin{array}{c}\text { Czech } \\
\text { Republic }\end{array}$ & $\begin{array}{c}\text { Slovak } \\
\text { Republic }\end{array}$ & Bulgaria & Romania \\
\hline Ease of doing business & 70 & 46 & 63 & 41 & 51 & 56 \\
\hline Starting a business & 113 & 35 & 130 & 68 & 43 & 44 \\
\hline Dealing with construction permits & 164 & 86 & 76 & 56 & 119 & 84 \\
\hline Registering property & 86 & 41 & 47 & 9 & 62 & 92 \\
\hline Getting credit & 15 & 32 & 46 & 15 & 6 & 15 \\
\hline Protecting investors & 44 & 120 & 93 & 109 & 44 & 44 \\
\hline Paying taxes & 121 & 109 & 128 & 122 & 85 & 151 \\
\hline Trading across borders & 49 & 73 & 62 & 102 & 108 & 47 \\
\hline Enforcing contracts & 77 & 22 & 78 & 71 & 87 & 54 \\
\hline Closing a business & 81 & 62 & 32 & 33 & 83 & 102 \\
\hline
\end{tabular}

Table III. Ranks of countries in the World Bank's ranking of favouring business regulations in 183 economies by the Doing Business indicators. Source: World Bank, 2010, pp. 159-193; author's own calculations.

What is important in our context of Central European knowledge production is that higher education and innovation systems in Western European countries - as opposed to Central European countries - function in very competitive economies, and companies, including 
companies involved in research, development, and innovation, operate in relatively friendly legal and regulatory environments. Which brings us back to two ideas: first, expectations from higher education (and innovation) systems should not be exaggerated in globally less competitive economies (such as Central European economies), as opposed to more competitive economies in which all other components of competitiveness are in place. And, second, the role of higher education (and innovation) systems in Central Europe differs strongly from those in Western Europe due to a multitude of factors exogenous to higher education systems. The necessary (and measurable) need to 'catch up with the West' in such areas as infrastructure, technology or business sophistication may be viewed as more important, and consequently public funding may be directed more easily towards these areas than towards higher education or R\&D in public higher education. And, in assessing the level of public funding for university research in almost all new EU member states, it can be seen that this has been exactly the case in the last two decades. Which comes close to Aghion and Howitt's recent claim in The Economics of Growth that, generally, the closer a country is to the productivity frontier, the more it becomes urgent to invest in higher education to foster innovation (and therefore in the United States, growth will be enhanced by investing more in research education instead of in two-year colleges; Aghion \& Howitt, 2009, p. 312). Central European countries are not at the productivity frontier, as shown in the research sector by both low publication intensity and low patent intensity (not discussed in this article).

The fiscal constraints in which higher education in Central Europe operates are high and there are high levels of inter-sectoral competition for (scarce) public funding. To give a dramatic illustration of the point: Poland in the global competitiveness index consistently ranks dramatically low in the last few years in one of the publicly most expensive categories - infrastructure: quality of overall infrastructure is ranked 108th out of 139 economies, quality of roads ranked 131st, quality of port infrastructure is ranked 114th and quality of air transport infrastructure ranked 108th (Schwab, 2010 , p. 278). The three other countries are also generally ranked very low in all of these subindices of infrastructure, with the exception of railroad infrastructure in the Czech and Slovak Republics, as Table IV illustrates.

\begin{tabular}{lcccccc}
\hline & Poland & Hungary & $\begin{array}{c}\text { Czech } \\
\text { Republic }\end{array}$ & $\begin{array}{c}\text { Slovak } \\
\text { Republic }\end{array}$ & Bulgaria & Romania \\
\hline $\begin{array}{l}\text { Quality of overall } \\
\text { infrastructure }\end{array}$ & 108 & 49 & 37 & 65 & 120 & 136 \\
$\begin{array}{l}\text { Quality of roads } \\
\begin{array}{l}\text { Quality of railroad } \\
\text { infrastructure }\end{array}\end{array}$ & 131 & 63 & 80 & 67 & 135 & 134 \\
$\begin{array}{l}\text { Quality of air transport } \\
\text { infrastructure }\end{array}$ & 108 & 66 & 17 & 120 & 94 & 70 \\
\hline
\end{tabular}

Table IV. Ranks by selected indicators of the 'infrastructure' section.

Source: Schwab, 2010, pp. 111-299; author’s own calculations.

Thus, Central European knowledge production is not only performed in economies with different levels of competitiveness, and which operate in different regulatory frameworks than most economically advanced Western European countries, as discussed above. Knowledge production is also performed in different, although convergent in the last two decades, labour markets and corresponding employment patterns, leading towards the service economy. There is a tendency for employment structures in Poland and other Central European countries to become similar to those in major OECD economies. In Poland, between 1994 and 2004, the share of those employed in agriculture and forestry decreased (from $24 \%$ to $18 \%$ ), those employed in manufacturing also decreased (from $32 \%$ to $29 \%$ ), and those employed in services increased substantially, from $44 \%$ to $53 \%$. This is still far below the OECD average in terms of employment patterns, but in terms of GDP by sector, the share of services is $66 \%$, close to the OECD average of about $70 \%$. The substantial difference, though, is that the service sector is composed of various activities, only some of which are knowledge-intensive. Central European countries lag behind in the share of knowledge-intensive service activities (which reaches $25-30 \%$ in the USA, France, and the UK [Wölfl, 2005, p. 9]). In the business sector in Poland, for instance, there are only four companies 
with considerable (but still marginal by OECD standards) R\&D investments - BRE Bank, Telekomunikacja Polska, Netia, and Orlen, with R\&D funding between 5 and 23 million EUR (in 2007). The above factors have a strong impact on the realities of knowledge production in higher education institutions, including on their ability to do research in partnership with the enterprise sector.

Finally, as well as countries being treated as units of analysis in knowledge-production assessment, in recent years, regions (referred to as NUTS 2 level) in European countries are also increasingly becoming the focus of attention of both researchers and policymakers (see Goddard, 2000; Hanell \& Neubauer, 2006; Arbo \& Benneworth, 2007; OECD, 2007; EC, 2009). A report entitled Europe's Regional Research Systems: current trends and structures published by the European Commission (EC, 2009) presents a new typology of regions which is very relevant for the assessment of knowledge production in Central Europe.

There are six leading R\&D performers in Europe (three regions in Germany and one each in the Netherlands, Finland and Sweden). All other regions in the European Union (EU) are classified into four types: Type 1 regions are R\&D-driven regions (a high publishing and a very high patenting intensity; business sector contributes an above-average share to regional GERD) [5]; Type 2 regions are public-sector-centred, R\&D-supported regions (with a very high publishing intensity in contrast to an only slightly above-average patenting intensity; gross expenditures for R\&D per GDP are slightly above average, mostly accounted for by either universities or public research institutions; the contribution of the business sector is below average); Type 3 regions are broadly based, R\&D-supported regions (with an average publishing and patenting intensity; unlike Type 1 or Type 2 regions, they are not home to outstanding centres of excellence in either public sector or business research); and finally, Type 4 regions comprise the remaining regions in which R\&D plays a small role (with a far below average publishing intensity, a very low patenting intensity and an amount of investment in R\&D 'that can only be described as complementary to the region's main drivers of growth' [EC, 2009, p. 40]).

With an exception of merely two regions (the Praha region in the Czech Republic and the Bratislavsky kraj region in the Slovak Republic), all regions in Central Europe (as well as, presumably, in Romania and Bulgaria, for which data are not available in a comparable format) are classified as either Type 3 or Type 4 regions, the vast majority of them being classified as Type 4 regions. Central European regions are weakest in research intensity and the least research-driven in the European Union.

A number of countries - including the four in Central Europe studied here - consist of Type 3 and Type 4 regions only (with the two above exceptions). The EC report concludes: 'it is likely that within their national context they lack sources of knowledge to which an enlarged ERA network could provide access' (EC, 2009, p. 44). A report entitled Geographies of Knowledge Production in Europe published by NORDREGIO (Nordic Center for Spatial Development) (Hanell \& Neubauer, 2006) stresses in its conclusions 'a clear core-periphery pattern' in the structure of knowledge intensity in Europe. 'The East-West divide in Europe' - the theme of the present article - is 'still clearly discernable' (Hanell \& Neubauer, 2006, p. 28). Consequently, knowledge production in Central Europe, at a regional level, is performed in regions which are not R\&D-driven: in the vast majority of regions, R\&D plays a supportive role or R\&D is merely complementary to the local economy.

\section{Conclusions}

A fair assessment of knowledge production in the region needs to refer back to historical legacies of the communist system and to two decades of its post-communist transformations. Universities in Central Europe for half a century were operating under special circumstances, with far-reaching consequences for the post-communist transition period and beyond. The early 1990 s brought about rapid political and economic transformations, while in the next ten years the reform packages also included welfare policies and higher education policies. Despite a powerful role of European agendas in transforming higher education systems in the region in the 2000s, both prior to and following the EU accession in 2004, Central European higher education still struggles with communist and post-communist legacies. Consequently, social narratives, or founding ideas, about 
the role of universities in society and in the economy produced by universities themselves are relatively weak, as opposed to strong narratives increasingly produced by policymakers involved in comprehensive reform programmes (as in Poland in 2008-2011).

The East/West divide in knowledge production continues, as testified by assessments of both higher education and innovation systems and by simplified global rankings of competitiveness of which both parts are important components. In economic rankings, the two pillars of economic competitiveness related to higher education (higher education and training, and innovation) in the four countries are weak, as are both research and patenting outputs. The role of factors other than higher education and innovation systems is substantially more important for competitiveness and growth in Central Europe than it is in affluent western economies. The international visibility of universities as knowledge production centres is extremely low, with just a few of them present in either global or European university rankings. The analysis of the geography of knowledge production at the level of regions may indicate that Central Europe is in danger of being effectively cut off from the emergent European Research Area. The very idea of knowledge economies may be far more difficult to apply in the region than is generally accepted in OECD and EC discourse.

The East/West differences in higher education systems and in university knowledge production may be bigger than expected, and the role of historical legacies may be more long term than generally assumed in both social science and public policy studies on the region. The transformation of universities may take much longer, and the gradual convergence of both higher education and research systems in the two parts of Europe cannot be taken for granted without thoughtful changes in both university funding (in terms of both modes and levels) and governance. Central European universities desperately struggle to remain in the global academic centre, but their gradual decline to the academic peripheries cannot be excluded.

\section{Notes}

[1] A shorter version of the article has been published in Universities in the Knowledge Economy: higher education organization and global change, ed. Paul Temple (Routledge, 2012). I would like to thank Paul Temple, as well as Martin Lawn and two anonymous readers for EERJ, for very helpful comments on an earlier version of this article. All limitations remain my sole responsibility, though.

[2] The article focuses on 'Central Europe' rather than on (more traditional in social sciences and economics) 'Central and Eastern Europe'; although for almost two decades Central and Eastern Europe (CEE) was the major political, economic, social and geographic point of reference in research into post-communist transition countries, the countries in question have become too diversified today to analyse them under a single label.

[3] It could also be accompanied by references to other indexes, such as, especially: IMD World Competitiveness Scoreboard 2010; BCI Business Competitiveness Index 2009-2010; The Lisbon Review 2010: Towards a More Competitive Europe; as well as World Bank: Knowledge Economy Score Board 2009 for Central European Countries. However, the overall results regarding knowledge production would not be very different.

[4] Apart from two pillars studied here (higher education and training, and innovation), the other ten pillars of competitiveness are: institutions; infrastructure; macroeconomy; goods market efficiency; labour market efficiency; financial market sophistication; technological readiness; market size; business sophistication; and, last but not least, and of interest to us here as well, innovation. They are often interdependent and try to reinforce each other (Porter et al, 2008, pp. 3-6).

[5] GERD stands for gross domestic expenditure on research and development.

\section{References}

Aghion, P. \& Howitt, P. (2009) The Economics of Growth. Cambridge, MA: MIT Press.

Arbo, P. \& Benneworth, P. (2007) Understanding the Regional Contribution of Higher Education Institutions. Paris: Organisation for Economic Cooperation and Development/IMHE - Programme on Institutional Management in Higher Education.

Barr, N. (2001). The Welfare State as Piggy Bank: information, risk, uncertainty, and the role of the state. Oxford: Oxford University Press. http: / / dx.doi.org/10.1093/0199246599.001.0001 
Barr N. (Ed.) (2005). Labor Markets and Social Policy in Central and Eastern Europe: the accession and beyond. Oxford: Oxford University Press.

Berend, I.T. (2007) Social Shock in Transforming Central and Eastern Europe, Communist and Post-Communist Studies, 40(3), 269-280. http:/ / dx.doi.org/10.1016/j.postcomstud.2007.06.007

Bonaccorsi, A. \& Daraio, C. (Eds) (2007) Universities and Strategic Knowledge Creation: specialization and performance in Europe. Cheltenham: Edward Elgar.

Brunsson, N. \& Sahlin-Andersson, K. (2000) Constructing Organizations: the example of public sector reform, Organization Studies, 21(4), 721-746. http: / / dx.doi.org/10.1177/0170840600214003

Castles, F.G., Leibfried, S., Lewis, J., Obinger, H. \& Pierson, C. (Eds) (2010) The Oxford Handbook of the Welfare State. Oxford: Oxford University Press.

Cunning, M., Godfrey, M. \& Holzer-Zelazewska, D. (2007) Vocational Education in the New EU Member States. Washington DC: World Bank. http: / / dx.doi.org/10.1596/978-0-8213-7157-2

Elster, J., Offe, C. \& Preuss, U.K. (1998) Institutional Design in Post-Communist Societies: rebuilding the ship at sea. Cambridge: Cambridge University Press. http:/ / dx.doi.org/10.1017/CBO9780511628351

European Commission (EC) (2009) Europe's Regional Research Systems: current trends and structures. Brussels: European Commission.

Foray, D. (2006) The Economics of Knowledge. Cambridge, MA: MIT Press.

Goddard, J. (2000) The Response of HEIs to Regional Needs. Newcastle upon Tyne: University of Newcastle upon Tyne.

Hannell T. \& Neubauer, J. (2006) Geographies of Knowledge Production in Europe. Stockholm: NORDREGIO (Nordic Center for Spatial Development).

Hazelkorn, E. (2011) Rankings and the Reshaping of Higher Education: the battle for world-class excellence. New York: Palgrave Macmillan. http: / / dx.doi.org/10.1057/9780230306394

Inglot, T. (2005) From Theory to Practice: lessons of postcommunist social policy reforms in Central Europe, in M. Cain, N. Gelazis \& T. Inglot (Eds) Fighting Poverty and Reforming Social Security: what can post-Soviet states learn from the new democracies of Central Europe? Washington DC: Woodrow Wilson Center.

Inglot, T. (2008) Welfare States in East Central Europe 1919-2004. Cambridge: Cambridge University Press. http: / / dx.doi.org/10.1017/CBO9780511510175

Kwiek, M. (2007) The University and the Welfare State in Transition: changing public services in a wider context, in D. Epstein, R. Boden, R. Deem, F. Rizvi \& S. Wright (Eds) World Yearbook of Education 2008, pp. 32-50. New York: Routledge.

Kwiek, M. (2008a) Academic Entrepreneurship vs. Changing Governance and Institutional Management Structures at European Universities, Policy Futures in Education, 6(6), 757-770. http:/ / dx.doi.org/10.2304/pfie.2008.6.6.757

Kwiek, M. (2008b) Entrepreneurialism and Private Higher Education in Europe, in Michael Shattock (Ed.) Entrepreneurialism in Universities and the Knowledge Economy, pp. 100-120. Maidenhead: Open University Press/McGraw-Hill.

Kwiek, M. (2008c) Accessibility and Equity, Market Forces and Entrepreneurship: developments in higher education in Central and Eastern Europe, Higher Education Management and Policy, 20(1), 89-110.

Kwiek, M. (2009) The Two Decades of Privatization in Polish Higher Education: cost-sharing, equity and access, in Jane Knight (Ed.) Financing Higher Education: equity and access, pp. 149-168. Rotterdam: Sense Publishers.

Kwiek, M. (2010) Creeping Marketization: where Polish private and public higher education sectors meet, in Roger Brown (Ed) Higher Education and the Market, pp. 135-146. New York: Routledge.

Kwiek, M. (2011) The Public-Private Dynamics in Polish Higher Education: demand-absorbing private growth and its implications, Higher Education Forum, 8, 101-124.

Kwiek, M. \& Maassen, P. (Eds) (2012, forthcoming) National Higher Education Reforms in a European Context: comparative reflections on Poland and Norway. Frankfurt: Peter Lang.

Leydessdorf, L. (2006) The Knowledge-Based Economy: modeled, measured, simulated. Boca Raton, FL: Universal Publishers.

Maassen, P. \& Olsen, J.P. (Eds) (2007) University Dynamics and European Integration. Dordrecht: Springer.

Mateju, P., Rehakova, B. \& Simonova, N. (2007) The Czech Republic: structural growth of inequality in access to higher education, in Y. Shavit, R. Arum \& A. Gamoran (Eds) Stratification in Higher Education: a comparative study, pp. 374-399. Stanford, CA: Stanford University Press. 
Meyer, J.W., Ramirez, F.O., Frank, D.J. \& Schofer, E. (2007) Higher Education as an Institution, in Patricia Gumport (Ed.) Sociology of Higher Education: contributions and their contexts, pp. 187-221. Baltimore: Johns Hopkins University Press.

Mora, J.-G., Detmer, A. \& Vieira, M.-J. (Eds) (2010) Good Practices in University-Enterprise Partnerships (GOODUEP). Valencia: Centre for the Study of Higher Education Management.

Orenstein, M.A. (2008) Postcommunist Welfare States, Journal of Democracy, 19(4), 80-94. http: / / dx.doi.org/10.1353/jod.0.0038

Orenstein, M.A. \& M.R. Haas (2005) Globalization and the Future of Welfare States in Post-Communist EastCentral European Countries, in M. Glatzer \& D. Rueschemeyer (Eds) Globalization and the Future of the Welfare State, pp. 130-152. Pittsburgh: University of Pittsburgh Press.

Organisation for Economic Cooperation and Development (OECD) (1996) The Knowledge-Based Economy. Paris: OECD.

Organisation for Economic Cooperation and Development (OECD) (2007) Higher Education and Regions: globally competitive, locally engaged. Paris: OECD.

Organisation for Economic Cooperation and Development (OECD) (2008) Higher Education at a Glance. Paris: OECD.

Pedersen, O.K. (2010) Institutional Competitiveness: how nations came to compete, in G. Morgan, J. Campbell, C. Crouch, O.K. Pedersen \& R. Whitley (Eds) The Oxford Handbook of Comparative Institutional Analysis. Oxford: Oxford University Press. http: / / dx.doi.org/10.1093/ oxfordhb/9780199233762.003.0023

Porter, M.E. (1990) The Competitive Advantage of Nations. New York: The Free Press.

Porter, M.E., Sala-i-Martin, X. \& Schwab, K. (2008) The Global Competitiveness Report 2007-2008. New York: Palgrave.

Ramirez, F.O. (2006) The Rationalization of Universities, in M.-L. Djelic \& K. Sahlin-Andersson (Eds) Transnational Governance: institutional dynamics of regulation, pp. 225-246. Cambridge: Cambridge University Press.

Schwab, K. (2010) The Global Competitiveness Report 2010-2011. New York: Palgrave.

Scott, P. (2007a) Higher Education in Central and Eastern Europe, in W.J.J. Forest \& P.G. Altbach (Eds) International Handbook of Higher Education. Dordrecht: Springer.

Scott, P. (2007b) Reflections on Private Higher Education Tendencies in Central and Eastern Europe, in S. Slantcheva \& D.C. Levy (Eds) Private Higher Education in Post-Communist Europe: in search of legitimacy. New York: Palgrave.

Shattock, M. (2008) Entrepreneurialism in Universities and the Knowledge Economy: diversification and organizational change in European higher education. Maidenhead: Open University Press/Society for Research into Higher Education.

Slantcheva, S. \& Levy, D.C. (Eds) (2007) Private Higher Education in Post-Communist Europe: in search of legitimacy. New York: Palgrave.

Stehr, N. (1994) Knowledge Societies. London: Sage.

Stehr, N. (2002) Knowledge and Economic Conduct: the social foundations of the modern economy. Toronto: University of Toronto Press.

Teichler, Ulrich (2011) The Future of University Rankings, in J.C. Shin, R.K. Toutkoushian \& U. Teichler (Eds) University Rankings: theoretical basis, methodology and impacts on global higher education. Dordrecht: Springer.

Temple, P. (2008) Teaching and Learning: an entrepreneurial perspective, in M. Shattock (Ed.) Entrepreneurialism in Universities and the Knowledge Economy. Diversification and Organizational Change in European Higher Education, pp. 49-62. Maidenhead: Open University Press.

Tomka, B. (2005) The Politics of Institutionalized Volatility: lessons from East Central European welfare reforms, in M. Cain, N. Gelazis \& T. Inglot (Eds) Fighting Poverty and Reforming Social Security: what can post-Soviet states learn from the new democracies of central Europe? Washington, DC: Woodrow Wilson Center.

Tomusk, V. (2004) The Open World and Closed Societies: essays on higher education 'in transition'. New York: Palgrave.

Wölfl, A. (2005) The Service Economy in OECD Countries. OECD Science, Technology and Industry Working Papers 2005/2. Paris: Organisation for Economic Cooperation and Development. 
World Bank (2007) Building Knowledge Economies: advanced strategies for development. Washington, DC: World Bank.

World Bank (2010) Doing Business 2011: making a difference for entrepreneurs. Washington, DC: World Bank.

MAREK KWIEK is Professor and Director of the Center for Public Policy Studies at Poznan University, Poland. His research interests include supranational educational policies, public sector reforms, the academic profession, and academic entrepreneurialism. His recent books include The University and the State: a study into global transformation (2006), Knowledge Production in European Universities: states, markets, and academics, and The Modernization of European Universities (with A. Kurkiewicz). He has been an expert to the European Commission, USAID, OECD, the World Bank, UNESCO, OSCE, the Council of Europe, and UNDP. Apart from about 20 international policy projects, he has participated in about 20 international comparative research projects, most recently in EUROAC - The Academic Profession in Europe (2009-2012, ESF), 6th Framework Programme project EUEREK: European Universities for Entrepreneurship (2004-2007), and GOODUEP Good Practices in University-Enterprise Partnerships (2007-2009, an EU LLL Multilateral Project). Correspondence:kwiekm@amu.edu.pl 